\title{
Influence of Simazin 50 and Dicuran on oxidative phosphory- lation in the mitochondria of spring barley (Damazy) embryos
}

\section{J. TŁUCZKIEWICZ}

Institute of Plant Biology, Technical Academy of Agriculture, Olsztyn 5, Poland (Received: February 7, 1973)

Abstract

Oxidative phosphorylation was investigated in the embryos of spring barley (Damazy) grain collected from plants sprayed in the period of shooting with Simazin 50 (2-chloro-4,6-etylamino-S-triazine) and Dicuran (N.3-chloro-4-methylphenol) $\mathrm{N}^{\prime}, \mathrm{N}^{\prime}$ dimethylurea) as well as in embryos of grains germinated in solutions of these herbicides and in 2,4-dinitrophenol.

The analyses were performed on grain of varying ripeness (waxy, full post-harvest dormancy) and at various stages of germination (24, $48 \mathrm{~h})$. It was found that the herbicides applied reduced succinate oxidation by the embryonal mitochondria and also depressed to the same exten the estirification of inorganic phosphate. Owing to this the $\mathrm{P} / \mathrm{O}$ ratio did not show significant changes.

Herbicide in germinated embryos solutions uncoupled oxidative phosphorylation. Simazin $50(3 \mathrm{~g} / \mathrm{l}$.$) and Dicuran (500 \mathrm{mg} / \mathrm{l}$.) exhibited a weaker effect than 2,4-dinitrophenol $\left(5 \times 10^{-4} \mathrm{M}\right)$. They, however, greatly reduced the oxidative activity of mitochondria what may have been caused by inhibition of electron transport in the respiratory chain.

\section{INTRODUCTION}

Herbicides - chemical agents for weed control - exert also a toxic influence on crop plants.

In the mechanism of action of S-triazine and phenylurea herbicides an unfavourable influence of these substances on the photosynthesis was observed. (Crafts, 1961; Moreland, 1967; Kearny and $\mathrm{K}$ a u $\mathrm{fm}$ a $\mathrm{n}, 1969)$. The disturbances caused by them are manifested in blocking of the Hill reaction ( $\mathrm{Cr}$ afts, 1961; M orela nd, 1967; M aštakov et al., 1971 (and in photosynthetic phosphorylation inhibition (Moreland, 1967; Mastakov et al., 1971; Moreland and B o ots 1971). 
In numerous publications mention may be found of a more extensive phytotoxic effect of S?triazin derivatives and phenylurea. They were found to inhibit growth of etiolated weed seedlings ( $\mathrm{Cr}$ a f $\mathrm{s}, 1961)$ and soy seedling ( $\mathrm{R}$ i e der et al., 1970), they also decrease the intensity of respiration of cucumber cotyledones (Foy and Penner, 1965), pea plants (La do n in and Spesivtse v, 1972) and of yeast cells (Inoue et al., 1967; $\mathrm{Hachimori}$ et al., 1968).

Some authors have also demonstrated a negative action of S-triazine and phenylurea derivatives on oxidative phosphorylation in the mitochondria of cabbage leaves (Lotlikar et al., 1968) in bean leaves (Moreland and Boots, 1971), in green pea plants (Ladonin and S pesivtsev, 1972) and in the hypocotyls of soy seedings ( $M$ c Da$\mathrm{niel}$ and Frans, 1969).

So far, however, data are lacking on the influence of these herbecides on oxidative phosphorylation in the mitochondria cereal grains.

The present study was undertaken in order to investigate:

1. the influence of Simazin 50 and Dicuran on oxidative phosphorylation in the mitochondria of spring barley (Damazy) embryos treated a single time with herbicides in the vegetation period;

2 . the direct influence of the above named agents on the phosphorylation process in the embryos of germinating barley grains;

3. the action of Simazin 50 and Dicuran in this respect as compared with that of 2,4-dinitrophenol (DNP).

\section{MATERIAL AND METHODS}

Preparation of material: the investigations were undertaken in 1971 on embryos of spring barley (Damazy) grains treated a single time with herbicides during the vegetation period. As control served embryos of grain collected from barley not treated with herbicides. Simazin 50 (Geigy) containing 50 per cent of simazin (2-chloro-4,6-ethylamine-Striazine) and Dicuran (Ciba) containing 80 per cent of chlorotolurone (N(3-chloro-4-methylphenol) $\mathrm{N}^{\prime}, \mathrm{N}^{\prime}$-dimethylurea) were used. Barley plants were sprayed with these herbicides at the beginning of shooting. A 0.3 per cent solution of Simazin 50 and a 0.2 per cent solution of Dicuran were applied in the amount of 1000 l./ha.

The embryos for analysis were free-hand isolated with a sectioning needle at $2-4^{\circ} \mathrm{C}$. Samples were collected in the following stages:

1. of waxy ripeness (30-34 days after pollination);

2. full ripeness (44-47 days after pollination);

3. post-harvest dormancy (20-24 days after the harvest);

4. after breaking of post-harvest dormancy (100-140 days after the harvest). 
At dough ripeness the embryos were isolated from freshly harvested grain. In the remaining periods of ripeness the embryos were separated out after 24-h swelling of the grain at $20^{\circ} \mathrm{C}$ on filter paper imbibed with water.

After breaking of the post-harvest dormancy, the embryos were isolated from grain, germinated for 24 and $48 \mathrm{~h}$ in identical conditions as the grain subjected to swelling.

In further experiments control grain (from barley not treated with herbicides) was germinated for 24 and $48 \mathrm{~h}$ on filter paper impregnated with Simazin $50\left(3 \mathrm{~g} / \mathrm{l}\right.$.), Dicuran $\left(500 \mathrm{mg} / \mathrm{l}\right.$.) and DNP $\left(5 \times 10^{-4} \mathrm{M}\right)$. 2,4-dinitrophenol was a product of The British Drug Houses Ltd. The herbicide solution applied after 3 days of germination, inhibited on the average by about 50 per cent the growth of etiolated barley sprouts.

Methods: Oxidative phosphorylation in the mitochondria of embryos was measured by the method described by $\mathrm{Kalin}$ in and Peltek (1968). Ten grams of embryos were ground in a porcelain mortar with $30 \mathrm{ml}$ of the extraction mixture containing $0.5 \mathrm{M}$ sucrose $0.005 \mathrm{M}$ EDTA and 2/15 M K-phosphate buffer $(\mathrm{pH} 7.3)$ - the end $\mathrm{pH}$ of the solution being 7.5. The homogenate was pressed through two layers of nylon and the filtrate was centrifuged for $15 \mathrm{~min}$ at $3800 \mathrm{~g}$. The supernatant was then centrifuged for $15 \mathrm{~min}$ at $8000 \mathrm{~g}$. The mitochondrial fraction obtained in this way was suspended in $5 \mathrm{ml}$ of the solution used for extraction and sedimented by centrifugation at $8000 \mathrm{~g}$ for $15 \mathrm{~min}$. The mitochondrial sediment was suspended in $0.5 \mathrm{M}$ sucrose prepared with $0.01 \mathrm{M}$ $\mathrm{K}$-phosphate buffer, $\mathrm{pH}$ 7.2. The mitochondrial suspension was placed in the vessels of a Warburg apparatus (0.5-0.7 $\mathrm{mg}$ mitochondrial $\mathrm{N}$ ), $1 \mathrm{ml}$ into each, into which previously the incubation mixture was poured and the wells were filled with $0.2 \mathrm{ml}$ of 20 per cent $\mathrm{KOH}$ each.

All operations from isolation of mitochondria to the moment of their transfer to the Warburg apparatus were performed at $0-2^{\circ} \mathrm{C}$. The incubation mixture in each vessel $(2 \mathrm{ml})$ contained, beside the mitochondrial suspension (in $\mu$ moles): sucrose -1000 , glucose -80 , ATP -6 , AMP -4 , $\mathrm{MgSO}_{4}-4$, potassium-phosphate buffer -30 as well as $1 \mathrm{mg}$ hexokinase, $1 \mathrm{mg}$ albumin and $0.1 \mathrm{mg}$ of cytochrome $c$. The substrate for oxidation was potassium succinate $(60 \mu$ moles $)$.

Oxidative phosphorylation of mitochondria was carried out in the Warburg apparatus at $25^{\circ} \mathrm{C}$ for $30 \mathrm{~min}$ with continuous shaking of the vessels (120 swings/min). The reaction was interrupted with $1 \mathrm{ml}$ of 20 pert cent trichloroacetic acid.

The oxidative activity of mitochondria was determined by the manometric method. Phosphorylative activity was assayed in terms of the difference in phosphate content between the incubation mixtures in endogenous respiration (without substrate) and exogenous respiration 
(with substrate). Inorganic phosphorus was determined after Fis ke$\mathrm{Subborow}$ (1925). The amount of oxygen taken up and amount of the phosphate incorporated was expressed in $\mu$ g-atoms per hour per $1 \mathrm{mg}$ of nitrogen of mitochondria. Mitochondrial nitrogen was determined by Kjeldahl's micromethod.

The results of oxidative phosphorylation here presented are means from two determinations. The differences between the replications of oxidation and phosphorylation determinations were 4-5 and 5-7 per cent, respectively.

\section{RESULTS AND DISCUSSION}

1. Influence of Simazin 50 and Dicuran applied during vegetation of barley on oxidative phosphorylation in the mitochondria of embryos.

The effect of Simazin 50 and Dicuran applied during the vegetation period on oxidative phosphorylation in the mitochondria of embryos of ripening barley grain is shown in Table 1 . The results indicate that Simazin 50 and Dicuran markedly depressed the oxidative (10-18\%) and phosphorylative (12-24\%) activity of mitochondria as compared with that of the controls at the time of waxy and full ripeness of the grain. In dormant grain no major influence of the two herbicides could be revealed. The $\mathrm{P} / \mathrm{O}$ ratio as compared with that in the control underwent slight changes at all stages of ripeness.

Table 1

Influence of Simazin 50 and Dicuran applied in the vegetation period on oxidative phosphorylation in mitochondria of embryos from spring barley (Damazy) in the stage of ripening

( $\mathrm{O}$ and $\mathrm{P}$ in $\mu \mathrm{g}$-atoms/hour/mg $\mathrm{N}$ of mitochondrial $\mathrm{N}$ )

\begin{tabular}{l|c|c|c}
\hline \multicolumn{1}{c|}{$\begin{array}{c}\text { Experimental } \\
\text { combination }\end{array}$} & $\mathrm{O}$ & $\mathrm{P}$ & $\mathrm{P} / \mathrm{O}$ \\
\hline & \multicolumn{3}{|c}{ waxy ripeness } \\
Control & 40,0 & $\mathbf{7 1 , 7}$ & 1,79 \\
Simazin 50 & 33,2 & 56,5 & 1,70 \\
Dicuran & 32,6 & 54,9 & 1,68 \\
& \multicolumn{3}{|c}{ full ripeness } \\
Control & 33,6 & 62,9 & 1,87 \\
Simazin 50 & 30,2 & 55,3 & 1,83 \\
Dicuran & 29,1 & 53,2 & 1,83 \\
& \multicolumn{3}{|c}{ post-harvest dormancy } \\
Control & 20,4 & 38,4 & 1,88 \\
Simazin 50 & 20,2 & 36,9 & 1,82 \\
Dicuran & 19,5 & 36,0 & 1,84 \\
\hline
\end{tabular}


$\mathrm{Table} 2$

Influence of Simazin $\mathbf{3 0}$ and Dicuran applied during vegetation period on oxidative phosphorylation in mitochondria of germinating grain embryos of spring barley (Damazy)

( $\mathrm{O}$ and $\mathrm{P}$ in $\mu \mathrm{g}$-atoms/hour/mg $\mathrm{N}$ of mitochondrial $\mathrm{N}$ )

\begin{tabular}{l|c|c|c}
\hline \multicolumn{1}{c|}{$\begin{array}{c}\text { Experimental } \\
\text { combination }\end{array}$} & $\mathrm{O}$ & $\mathrm{P}$ & $\mathrm{P} / \mathrm{O}$ \\
\hline & \multicolumn{3}{|c|}{ germinated $24 \mathrm{~h}$} \\
Control & 34,1 & $\mathbf{6 2 , 5}$ & 1,83 \\
Simazin 50 & 30,9 & $\mathbf{5 4 , 6}$ & 1,77 \\
Dicuran & 30,3 & 54,2 & 1,79 \\
& \multicolumn{3}{|c|}{ germinated $48 \mathrm{~h}$} \\
Control & 29,4 & 53,7 & 1,83 \\
Simazin 50 & 26,8 & $\mathbf{4 7 , 1}$ & 1,76 \\
Dicuran & 26,8 & $\mathbf{4 7 , 0}$ & 1,75 \\
\hline
\end{tabular}

The highest oxidative and phosphorylative activity was noted in the mitochondria of grain of waxy ripeness, it was lower in fully ripe grain and the lowest during post-harvest dormancy.

After breaking of the post-harvest dormancy of the grain, an unfavourable action (Table 2) of Simazin 50 and Dicuran on oxidate phosphorylation in the embryonal mitochondria could be demonstrated (but in a lesser degree). In both stages of germination a slight decrease in the oxidation and phosphorylation activity in the mitochondria was noted. The degree of coupling of oxidative phosphorylation ( $\mathrm{P} / \mathrm{O}$ ratio) was in this period close to the control value.

The results here reported point to a very weak uncoupling influence of Simazin 50 and Dicuran applied during vegetation on the oxidative phosphorylation process in the embryos. The herbicides distinctly lowered, however, the ability of mitochondria to oxidate succinate and esterify inorganic phosphates.

The negative effect of Simazin 50 and Dicuran on oxidative phosphorylation in barley embryos may be due to their direct or indirect action. The possibility of their direct action results from their way of translocation and their location in plant tissues.

It is known from numerous reports ( $\mathrm{Cr}$ a f t s, 1961; $\mathrm{K}$ e a r nery and $\mathrm{Kaufm}$ a $\mathrm{n}$ 1969) that S-triazin and phenylurea herbicides travel with the transpiration stream and accumulate mainly in the apoplast of leaf mesophyll. Their presence has recently also been detected in cereal grain (Kostowska et al., 1971; Mielnikov, 1972) and in numerous cellular fractions (L adonin and Spesivtsev, 1972) among them in mitochondria. The accumulation level of S-triazin derivatives and phenylurea in cell protoplast decides of their toxicity and 
depends on the sensitivity of the given plant (Kearney and $\mathrm{Ka} \mathrm{uf}$ -

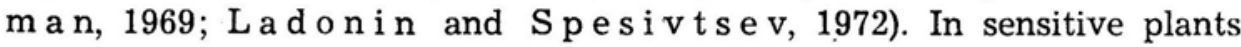
these preparations have a marked inhibitory effect of oxidative phosphorylation (Lotlikar et al., 1968; M c Daniel and Frans, 1969; Moreland and Boots, 1971; Ladonin and Spesivtsev, 1972).

An indirect cause of depression of oxidative phosphorylation in the embryos by the herbicides applied in the vegetation period were no doubt the changes in the biochemical and physiological properties of the entire plants induced by these agents ( $\mathrm{Cr}$ a fts, 1961; M o rela nd, 1967; M a š t a k o v et al., 1971) as well as in the grain harvested from these plants (Grzesiuk et al., 1971). In the latter case noteworthy in the fact that herbicides cause a rise in the level of phenol compounds in the plants ( $\mathrm{Crafts}, 1961 ; \mathrm{M}$ a štakov et al., 1971) and in cereal grain (Grzesiuk et al., 1971), whereas it is known that phenol compounds combining with mitochondrial protein may inhibit oxidative phosphorylation (Wein bach and G a r bus, 1964).

2. Changes in oxidative phosphorylation in embryonal mitochondria from grain germinating in Simazin 50, Dicuran and DNP solutions

It would seem that phenylurea and S-triazin herbicides disturb some stages of plant metabolism. Therefore in order to compare the action of these substance on oxidative phosphorylation, the herbicide concentration had to be adjusted so as to have a similar influence on the metabolism of germinating barley grain, irrespective of the differences be-

Table 3

Influence of various Simazin 50, Dicuran and DNP concentrations on growth of embryos from spring barley (Damazy)

(in each combination means from 50 determinations)

\begin{tabular}{|c|c|c|c|c|}
\hline \multirow[b]{2}{*}{$\begin{array}{l}\text { Experimental } \\
\text { combination }\end{array}$} & \multicolumn{2}{|c|}{ Length of germ } & \multicolumn{2}{|c|}{ D. wt. of embryo } \\
\hline & $\mathrm{mm}$ & $\begin{array}{l}\text { as } \% \text { of } \\
\text { control }\end{array}$ & mg & $\begin{array}{l}\text { as } \% \text { of } \\
\text { control }\end{array}$ \\
\hline Control & 18,2 & 100,0 & 6,5 & 100,0 \\
\hline Simazin $50-1 \mathrm{~g} / 1$ & 13,4 & 73,6 & 5,2 & 80,0 \\
\hline Simazin $50-2 \mathrm{~g} / 1$ & 11,2 & 61,5 & 4,6 & 70,8 \\
\hline Simazin $50-3 \mathrm{~g} / 1$ & 9,2 & 50,5 & 4,0 & 61,5 \\
\hline Control & 18,0 & 100,0 & 6,4 & 100,0 \\
\hline Dicuran - $100 \mathrm{mg} / 1$ & 12,3 & 68,3 & 5,1 & 79,7 \\
\hline Dicuran $-250 \mathrm{mg} / \mathrm{l}$ & 9,9 & 55,0 & 4,5 & 70,3 \\
\hline Dicuran $-500 \mathrm{mg} / 1$ & 8,7 & 48,3 & 3,6 & 54,7 \\
\hline Control & 18,1 & 100,0 & 6,4 & 100,0 \\
\hline DNP - $10^{-5} \mathrm{M}$ & 15,4 & 85,1 & 6,2 & 96,9 \\
\hline $\mathrm{DNP}-10^{-4} \mathrm{M}$ & 13,9 & 76,8 & 5,0 & 78,1 \\
\hline $\mathrm{DNP}-5 \cdot 10^{-4} \mathrm{M}$ & 8,2 & 45.3 & 3,4 & 53,1 \\
\hline
\end{tabular}




\section{Table 4}

Changes in oxidative phosphorylation in mitochondria of embryos of spring barley grain (Damazy) germinated in

Simazin 50, Dicuran and DNP solutions

( $\mathrm{O}$ and $\mathrm{P}$ in $\mu$ g-atoms/hour/mg $\mathrm{N}$ of mitochondrial $\mathrm{N}$ )

\begin{tabular}{|c|c|c|c|}
\hline $\begin{array}{l}\text { Experimental } \\
\text { combination }\end{array}$ & $\mathrm{O}$ & $\mathrm{P}$ & $\mathrm{P} / \mathrm{O}$ \\
\hline & \multicolumn{3}{|c|}{ germinated $24 \mathrm{~h}$} \\
\hline & & & \\
\hline Control & 33,5 & 61,7 & 1,84 \\
\hline Simazin $50-3 \mathrm{~g} / \mathrm{l}$ & 25,6 & 42,8 & 1,67 \\
\hline Dicuran $-500 \mathrm{mg} / \mathrm{l}$ & 24,0 & 36,5 & 1,52 \\
\hline \multirow[t]{2}{*}{$\mathrm{DNP}-5 \cdot 10^{-4} \mathrm{M}$} & 27,6 & 34,2 & 1,24 \\
\hline & \multicolumn{3}{|c|}{ germinated $48 \mathrm{~h}$} \\
\hline Control & 30,0 & 55,0 & 1,83 \\
\hline Simazin $50-3 \mathrm{~g} / 1$ & 20,1 & 34,0 & 1,68 \\
\hline Dicuran $-500 \mathrm{mg} / 1$ & 19,3 & 29,8 & 1,54 \\
\hline $\mathrm{DNP}-5 \cdot 10^{-4} \mathrm{M}$ & 23,3 & 27,7 & 1,19 \\
\hline
\end{tabular}

tween the agents applied. The concentrations were adjusted on the basis of comparison of their inhibitory influence on the growth of etiolated sprouts (Table 3 ).

This comparison showed DNP to be most, and Simazin 50 least phytotoxic; Dicuran held and intermediate position. A 50 per cent growth inhibition of etiolated sprouts by Simazin 50 and Dicuran occurred only when high concentrations were used (in active substances - simazin $1.5 \mathrm{~g} / \mathrm{l}$. and chlorotoluron $400 \mathrm{mg} / \mathrm{l}$ ), many times higher than in the case of DNP (92 mg/l.). Similar regularities were also demonstrated by Crafts (1961) and Rieder et al. (1970).

Changes in oxidative phosphorylation in barley embryos during germination in Simazin 50, Dicuran and DNP solutions inhibiting growth of etiolated sprouts in about 50 per cent are shown in Table 4 . When the grain was directly treated with herbicides a distinctly higher inhibitory effect on oxidative phosphorylation was observed than when they were applied in the vegetation period.

The P/O ratio was lowered, as compared with that of the control, by Simazin 50 by 10 , by Dicuran by $16-17$ and by DNP by 33-35 per cent. The greater disturbance of oxidation and phosphorylation by DNP than by the other herbicides was due to the fact that DNP inhibits less oxidation and depresses more phosphorylation than the other two agents.

The different inhibitory effect on oxidative phosphorylation of the 
tested herbicides was largely connected with their penetration rate into the embryonal cells and further to the mitochondria. Herbicides with a high ability of penetration through the mitochondrial membranes have a strong disturbing effect on phosphorylation (Bottrill and $\mathrm{Han}$ son, 1969; Maštakov et al., 1969; Ladonin and Spesivtsev 1972). Their action consists in disorganization of the respiratory chain processes and stimulation of mitochondrial ATP-ase activity (L i e ber$\mathrm{m}$ a n and B a ker, 1965; M a s tak ov et al., 1969). Herbicides may also cause structural degradation of mitochondria manifested in their excessive swelling, usually with limitation of their biochemical activity (Lieberman and Baker, 1965; Bottrill and Hanson, 1969; $\mathrm{M}$ a š tak ov et al., 1969).

The investigations here reported show that S-triazin and phenylurea herbicides have a different influence on oxidative phosphorylation than DNP. They reduced in isolated mitochondria the ability of succinate oxidation, depressing in this way phosphorylation associated with this process. The P/O ratio, however, was much less affected by these herbicides. A similar decrease of oxidation activity in plant mitochondria under the influence of S-triazin and phenylurea herbicides was noted by Lotlikar et al., (1968) and M c Daniel and Frans (1969).

The mode of action of these agents classifies Simazin 50 and Dicuran as inhibitors of electron transport in the mitochondrial respiratory chain (Lieberman and Baker, 1965). This view is partly confirmed by the inhibition of electron flow from cytochrome $b$ to cytochrome $c$ in yeast mitochondria by phenylurea (I n o u e et al., 1967; Hachimori et al., 1968) and S-triazin herbicides ( $\mathrm{Hachimori}$ et al., 1968). For full demonstration of this relationship, however, further investigations in this field are necessary.

\section{REFERENCES}

B ottril1 D., H a ns on J., 1969, Austral. J. Biol. Sc. 22; 846-855.

Crafts A. S., 1961, The chemistry and mode of action of herbicides, Inter. Publish - New York - Landon.

F i s ke C., Subbor ow Y., 1925, J. Biol. Chem. 66; 375-400.

F oy C., Penner D., 1965, W e d s 13; 226-231.

Grzesiuk St., Sójka E., Rotkiewi C D., 1971, Zesz. Probl. Post. Nauk Ro! $113 ; 141-161$.

Hachimori A., Nosoh Y., Some B., 1968, J. Bichem. Tokyo 64; 119-121. Inoue Y., Ishizuka K., Mitsui S., 1967, Agric. Biol. Chem. 31; 422-427.

Kalinin F., Peltek Ch., 1968, Ukr. Bioch. Zurnal 40; 202-204.

K e a r ney P., K a u f a n D., 1969, Degradation of herbicides, M. Dekker Inc. New York.

Kostowska B., Sadowski J., Witek S., Rola J., 1971, Pam. Pul. 46; 121-138. 
Ladonin V., Spesivcev G., 1972, Agrokhimija 1; 104-113.

Li e be rm an M., B a ker J., 1965, Ann. Rev. Plant Physiol. 16; 342-382.

Lotlikar P., Remert L., Freed V., 1968, Weed. Sc. 16; 161-165.

Maštakov S., Vojnilo V., Dejeva V., 1969, Fiziolog. Rast. 16; 111-119.

Maštakov S., Dejeva V., Volyniec A., Prochorchik R., Shcher-

bakov V., Kudriavcev G., 1971, Fiziologicheskoie dieistviie niekotorych

gerbicidov na rastienija, Izd. „Nauk i Tekhnika”, Minsk.

M c D a niel J., Frans R., 1969, Weed. Sc. 17; 192-196.

Mi eln i k ov N., 1972, Chim. siel-choz. 4; 28-34.

M ore la nd D., 1967, Ann. Rev. Plant Physiol. 18; 365-386.

M ore land D., B oots M., 1971, Plant Physiol. 47; 53-58.

Rieder G., Buchholtz K., Kust C., 1970, Weed. Sc. 18; 101-105.

Wej $\mathrm{nbach}$ E., Garbus J., 1964, Science $145 ; 824-826$.

\section{Wpływ Simazinu 50 i Dicuranu na fosforylację oksydacyjną} w mitochondriach zarodków jęczmienia jarego (Damazy)

\section{Streszczenie}

Badano proces fosforylacji oksydacyjnej $w$ zarodkach ziarna zebranego $\mathrm{z}$ jęczmienia jarego (Damazy), spryskanego w okresie wegetacji Simazinem 50 (2-chloro-4,6-etyloamino-S-triazyna) i Dicuranem (N/3-chloro-4-metylofenolo/ $\mathrm{N}^{\prime}, \mathrm{N}^{\prime} \mathrm{dwume}$ tylo-mocznika) oraz w zarodkach ziarna kontrolnego poddanego kielkowaniu w roztworach tych herbicydów i 2,4-dwunitrofenolu.

Analizy przeprowadzono w różnych okresach dojrzałości ziarna (woskowa, pelna, spoczynek posprzętny) i kiełkowania (w ciągu 24 i 48 godzin).

Stosowane $w$ okresie wegetacji jęczmienia herbicydy, hamowały zdolność mitochondriów zarodków do utleniania bursztynianu i estryfikacji fosforu nieorganicznego oraz nieznacznie zmienialy stosunek $\mathrm{P} / \mathrm{O}$ we wszystkich badanych etapach dojrzałości i kielkowania ziarna.

Kielkowanie ziarna $w$ roztworach herbicydów wywoływalo jeszcze większą inhibicję aktywności oksydacyjnej i fosforylacyjnej mitochondriów zarodków. Równocześnie zachodzilo wyraźne rozkojarzenie fosforylacji oksydacyjnej.

Simazin $50 \quad(3 \mathrm{~g} / \mathrm{l})$ i Dicuran $(500 \mathrm{mg} / \mathrm{l})$ w znacznie mniejszym stopniu niż 2,4-dwunitrofenol $\left(5 \cdot 10^{-4} \mathrm{M}\right)$ rozprzęgaly oksydacyjną fosforylację, lecz silniej hamowały utlenianie bursztynianu. Wskazywałoby to, że sposób działania Simazinu 50 i Dicuranu na ten proces mógł wynikać z inhibicji transportu elektronów w lańeuchu oddechowym mitochondriów. 